بهروز رسانى و بازنغرى سند ملى آب در دشتهاى قزوين و فومنات

محسن براهيمى " و ايران غازى

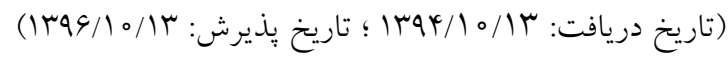

جكيده

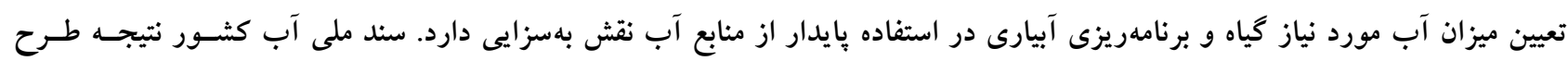

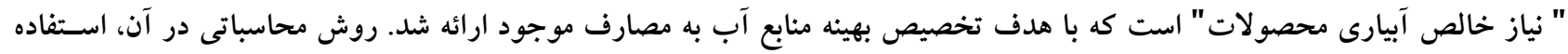

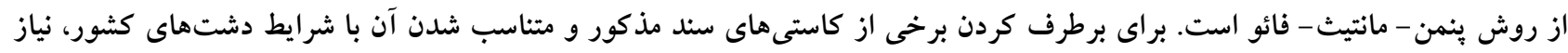

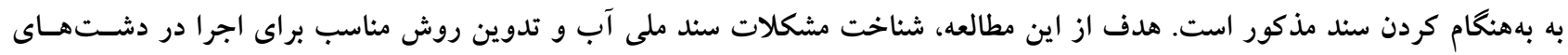

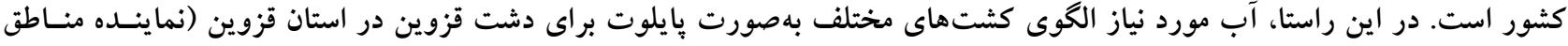

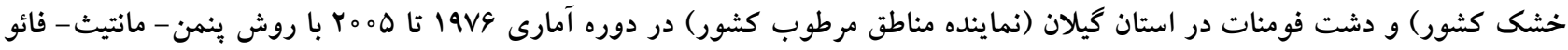

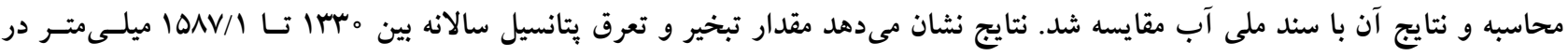

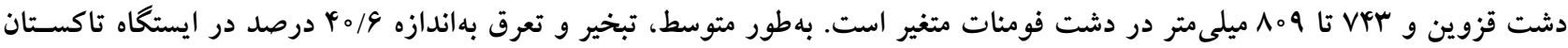

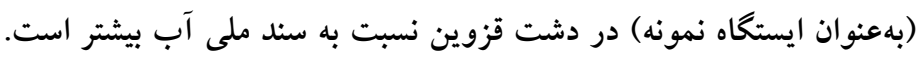

وازههاى كليدى: منابع آب، تخصيص بهينه، مناطق خشك و مرطوب

ا. كروه منابع آب، دانشكده مهندسى عمران، يُوهشخاه شاخص يزوه اصفهان

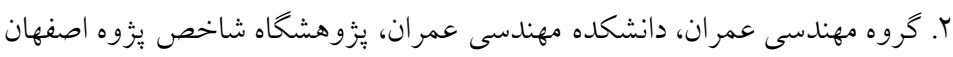

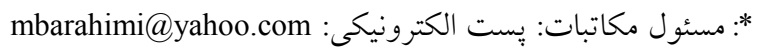


موارد كمتر ييشبينى كرده است. علت اين تفاوت در ميزان نيـاز

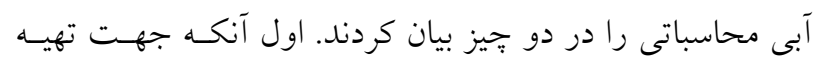

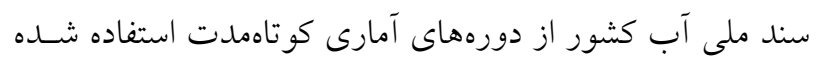

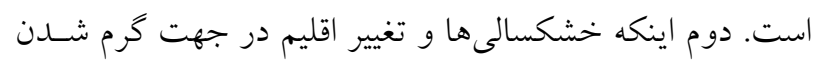

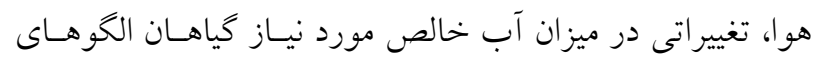
كشت مختلف در بيشتر اقليمها بهوجود آورده است. در نهايست،

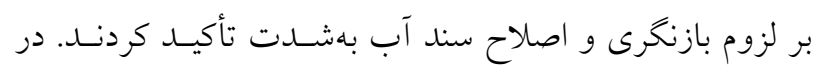

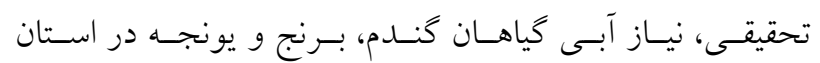

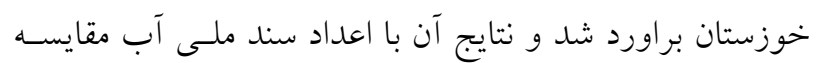

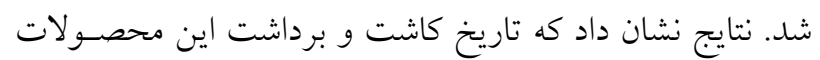
در استان خوزستان نياز به بهبود دارد (11). در تحقيق (1) بــراى مـدلســازى تبخيـر و تعـرق از شـبكه

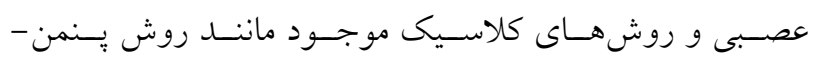

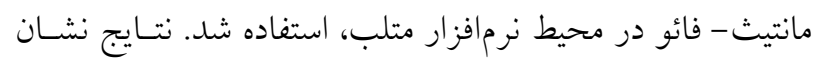

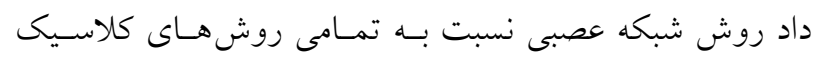
عملكرد بهترى دارد.

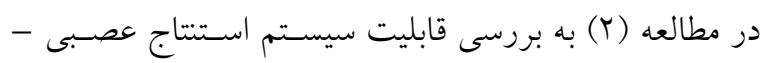
فازى تطبيقى در بهبود تخمين ميزان تبخير و تعرق روزانه كيـاه

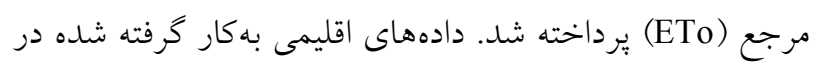

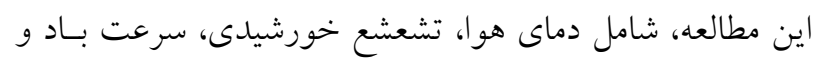

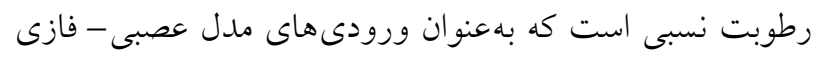

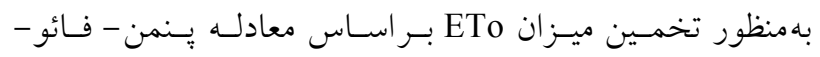

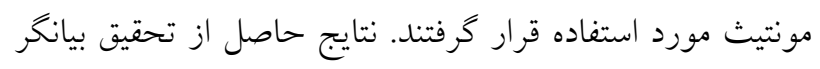

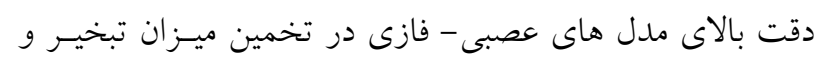

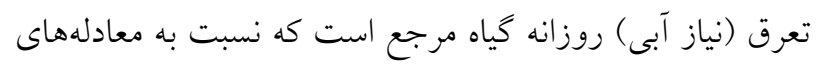
تجربى نتايج بهترى را نشان دادند.

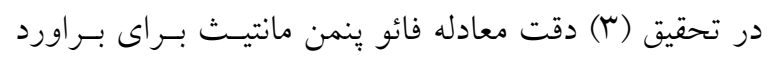

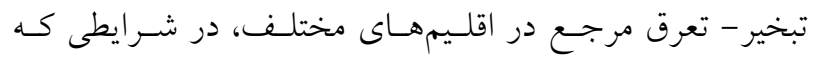
دادهاى هو اشناسى محدود باشند، بررسى شد. براى اين مطالعه

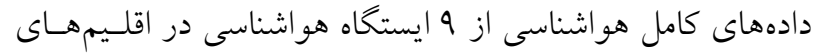

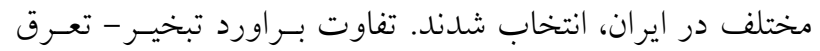

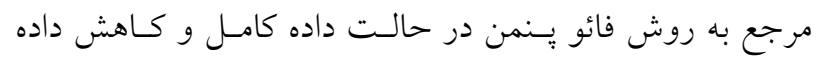

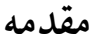

بحران شديد محدوديت منابع آبى در ايران بهدليل واقع بودن در

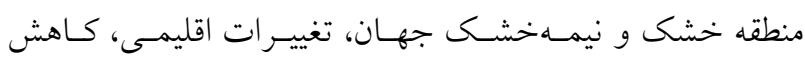

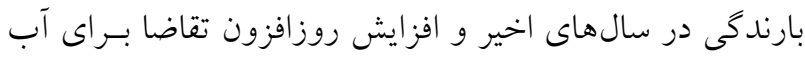

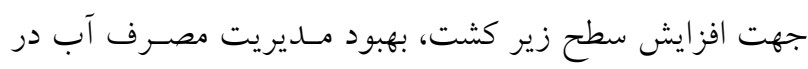

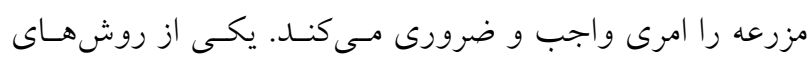

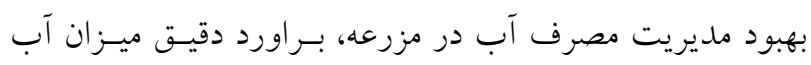
مصرفى كياهان است. در اين راسـتا، سـند ملـى آبيـارى كشـور

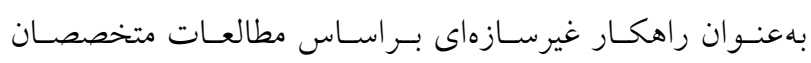

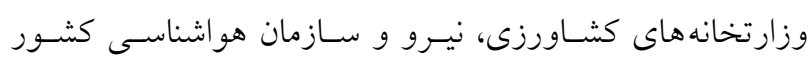
بهروش تو صيهشده توسط سازمان فائو تهيه و بـهـعنـوان مبنـايى ونسي

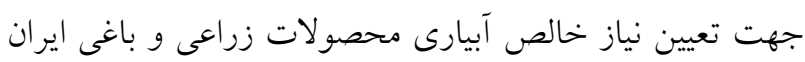
معرفى شد. رشد و توسعه هواشناسى در كشور و احداث ايستخاههـاى

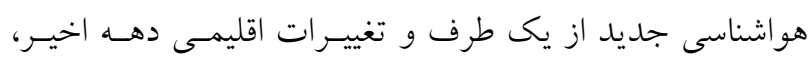

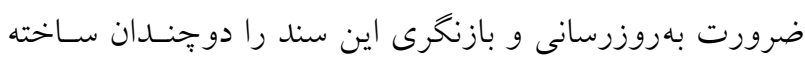
است. تحقيقات محمديان و همكاران (N) نشان داد كه بـهدليـل اثرات خشكى در بعضى از ايستخاههاى هو اشناسى استفاده شــده

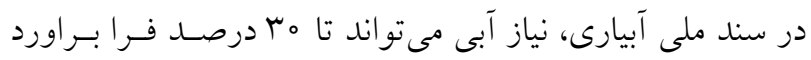

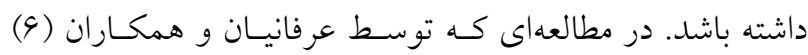

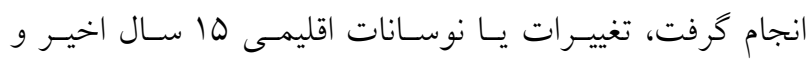

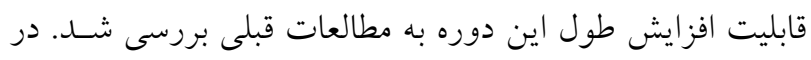

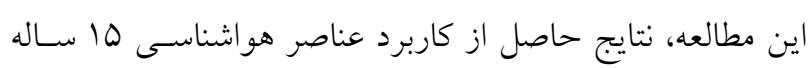

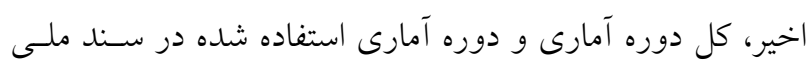

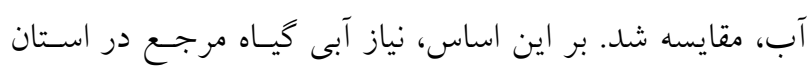

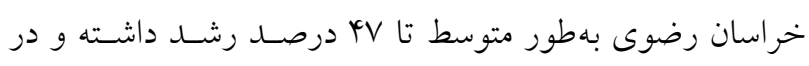
نهايت بر لزوم بازنخرى و بهروزرسانى سند ملى آب تأكيد شده رضه

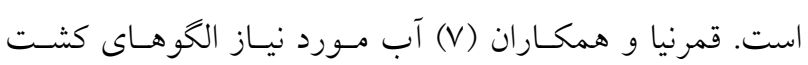

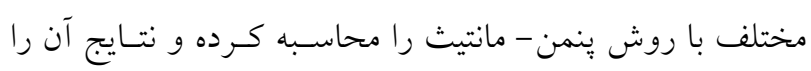

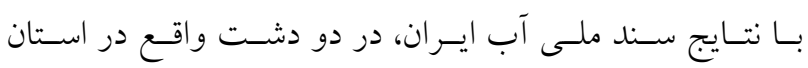

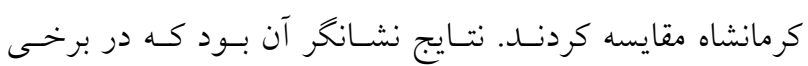

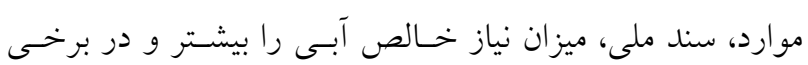


انتخاب ايستگاههاى مبنا است (ه).

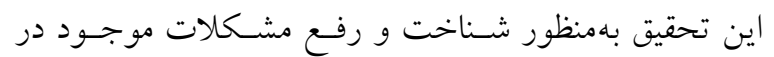

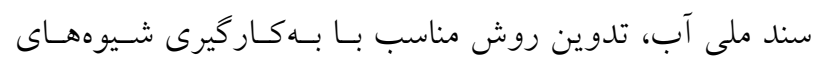
دقيق محاسباتى و توصيهها و روشهاى ارائه شده توسط FAO،

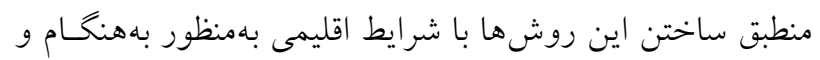

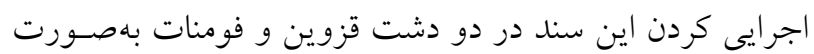

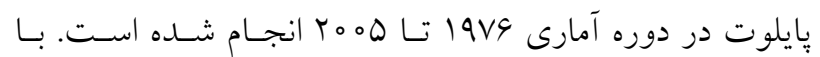

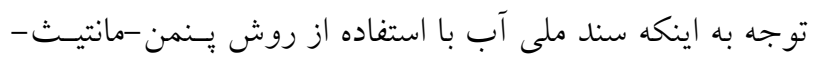
فائو انجام شده است و همجِنين هزينه بالاى استفاده از لايسيمتر در سطح دشت، در اين تحقيق نيز اين روش مورد استفاده قـرار

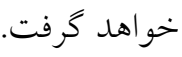

\section{مواد و روشها}

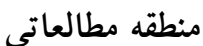

مناطق مورد مطالعه در اين تحقيق شامل دشت قزوين (بهعنـوان نماينده مناطق خشك كشور) در استان قزوين و دشـت فومنـات (بهعنوان نماينده مناطق مرطوب كشور) در استان كـيلان اسـت.

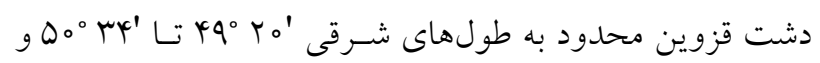

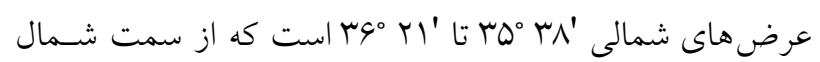

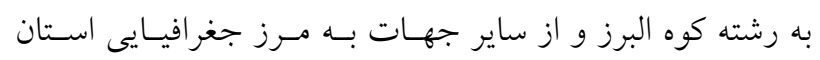

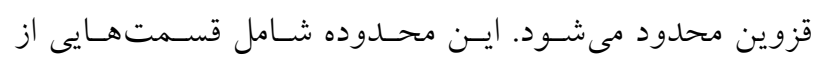

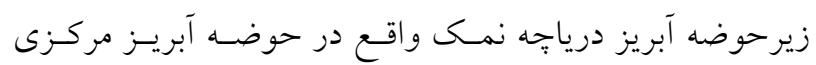

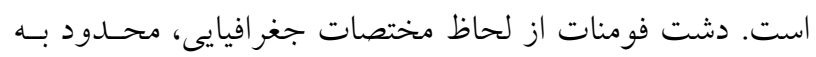

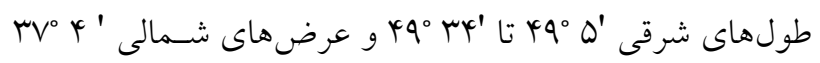

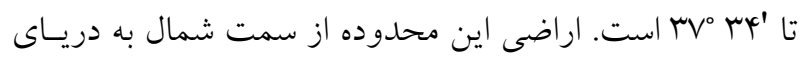

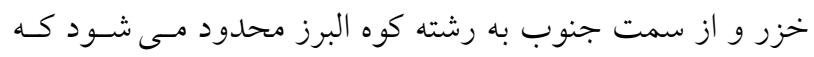

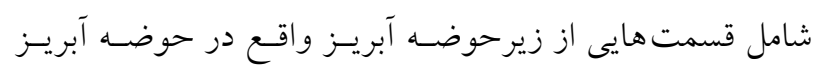

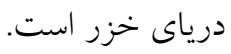

\section{مبانى سند ملى آب و نرمافزار OPTIWAT} از جمله نرمافزارهايى كه جهت براورد نياز آبى كشور تهيه شده است مىتوان به NETWAT و OPTIWAT اشاره كرد. نرمافزار

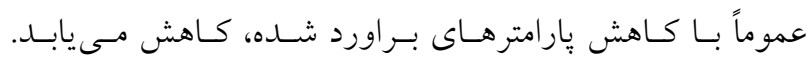

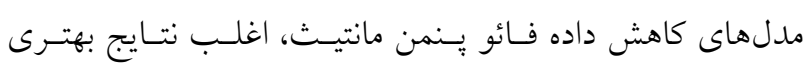

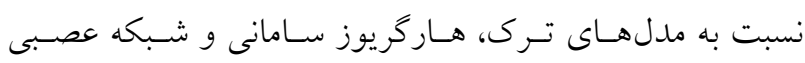

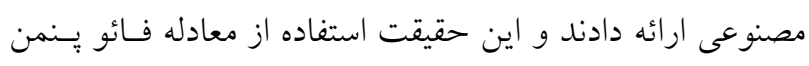

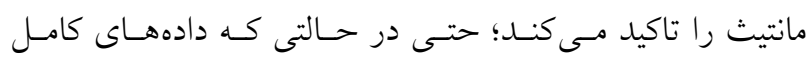
هواشناسى در دسترس نباشند.

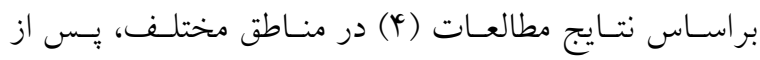

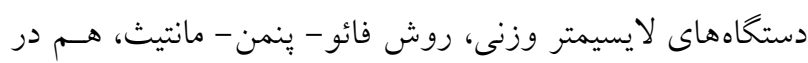

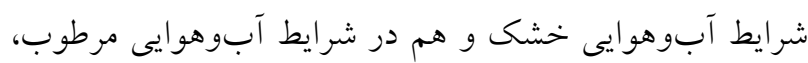
بهعنوان دقيقترين روش معرفى شده است. در اين مطالعه تبخير

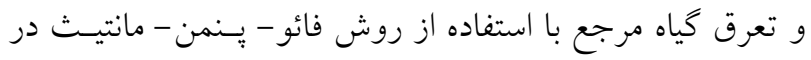

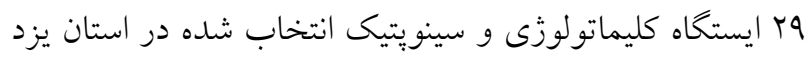

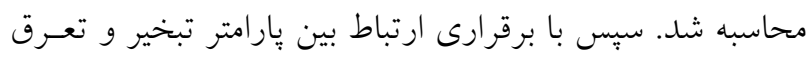

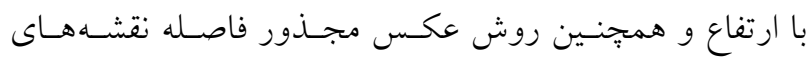

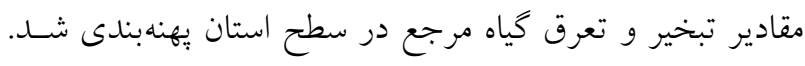

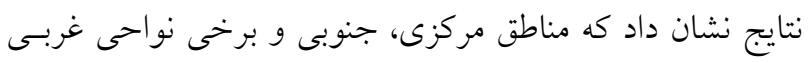

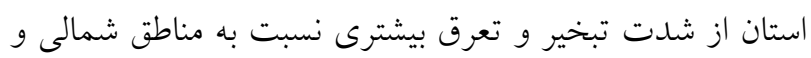
شرقى برخوردار هستند.

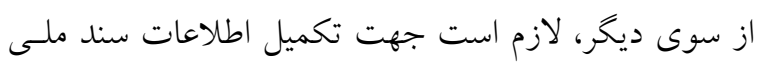

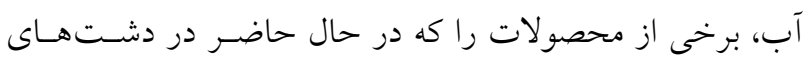

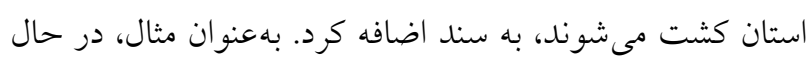

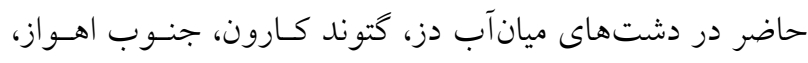
خلف آباد (رامشير) و دشت هنديجان برنج كشت مى دشود اما در دران

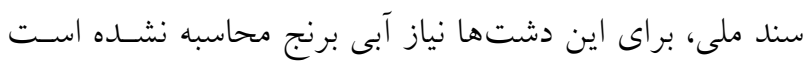

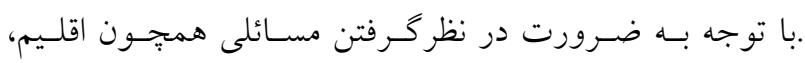

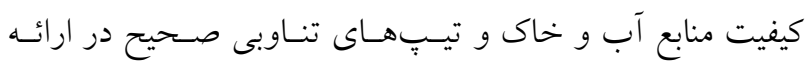

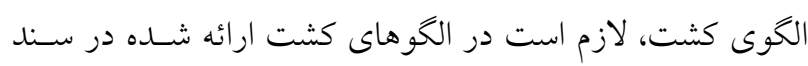

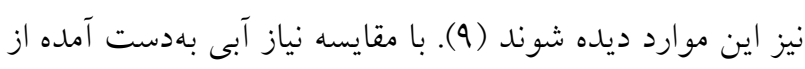

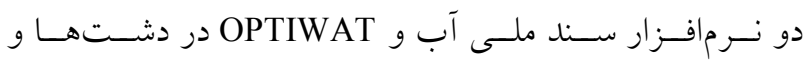

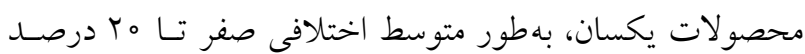

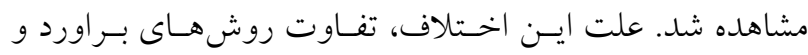

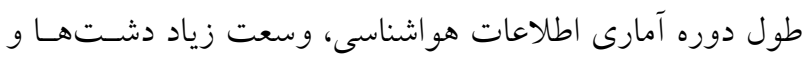


هواشناسى جهانى (WMO) استفاده شـــ قبـل از آنـاليز دادههـا

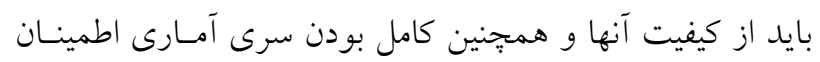

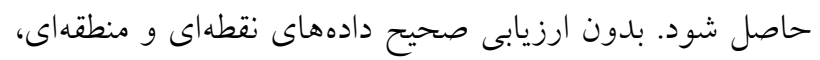

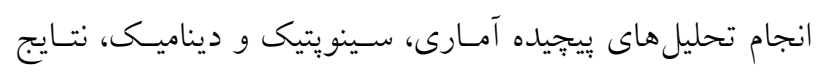

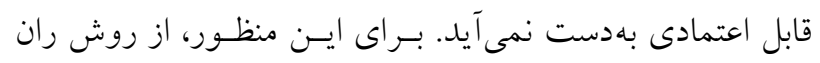

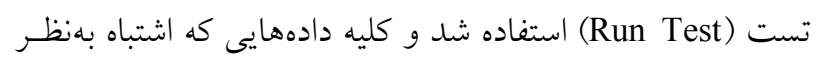

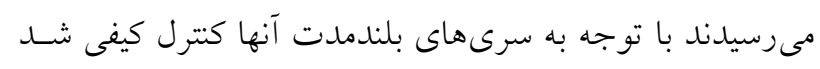

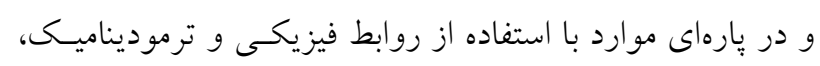

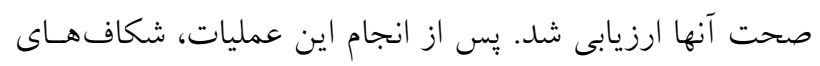

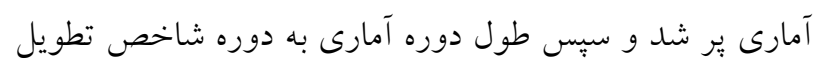

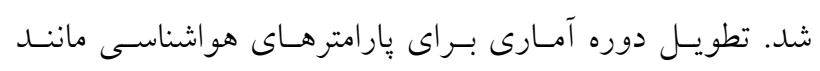

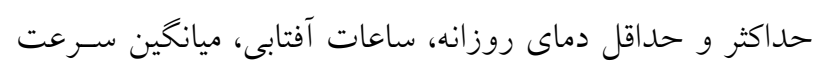

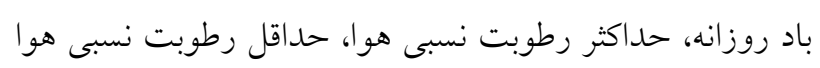

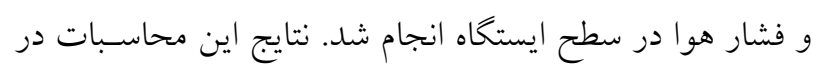

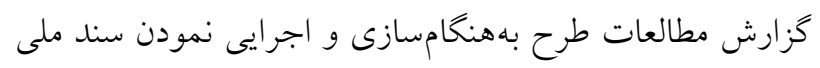

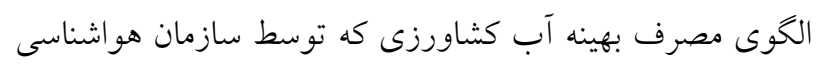

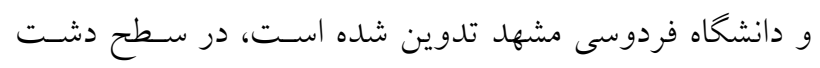
قزوين و فومنات ارائه شده است.

\section{براورد نياز آبى محصولات}

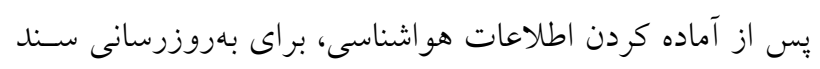

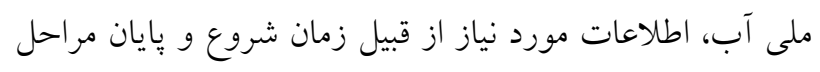

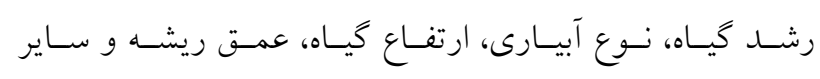

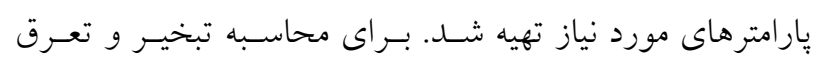

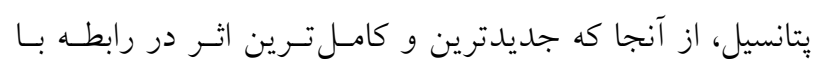

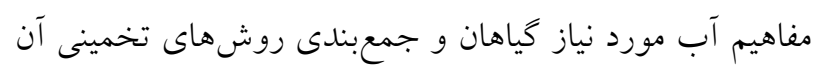

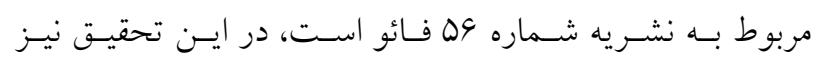

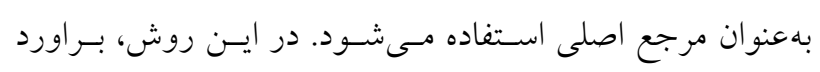

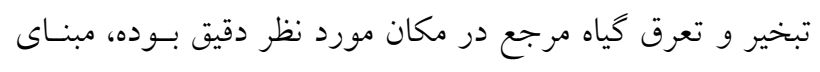

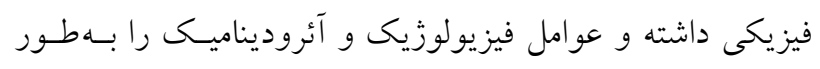

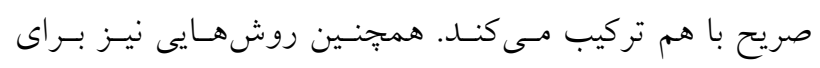

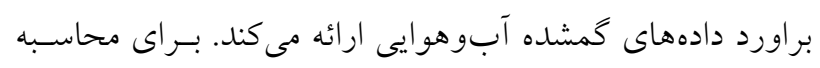

بPTIWAT نشريه شماره هو فائو تهيه شده است. با توجسه بــه اينكـه نتـايج تحقيق حاضر با نتايج نرمافزار OPTIWAT مقايسه مىشود، اين نرمافزار بهطور مختصر معرفى مىشود.

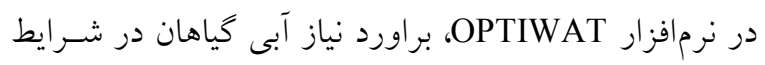

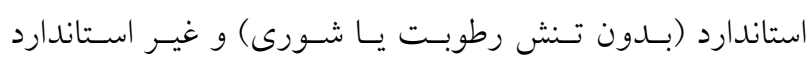

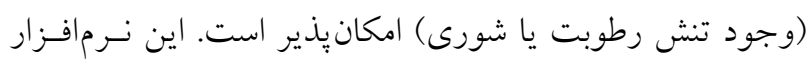

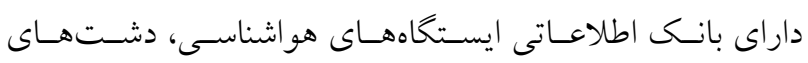

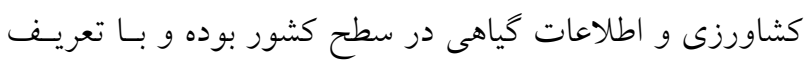

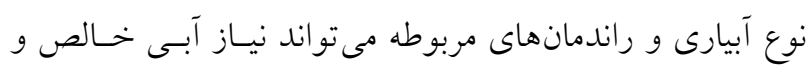

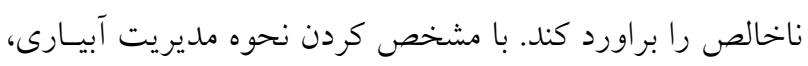

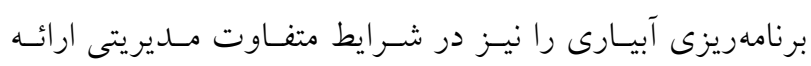

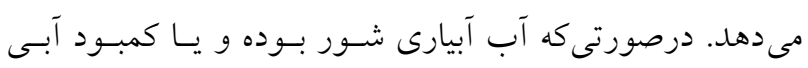

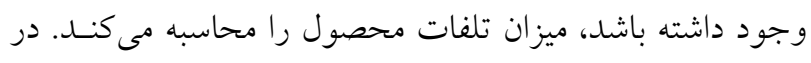

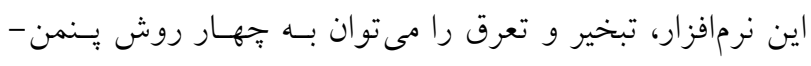

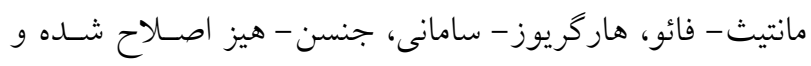

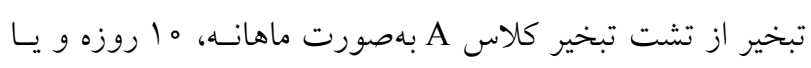
روزانه براورد كرد.

\section{مطالعات هواشناسى}

با توجه به اينكه بيشتر محاسـبات نيـاز آبسى گياهـان مبتنسى بـر

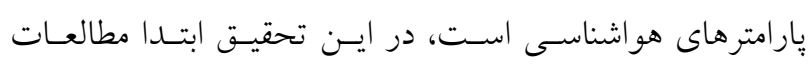

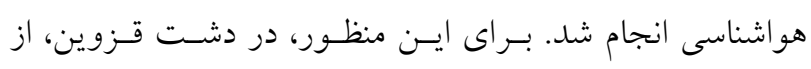

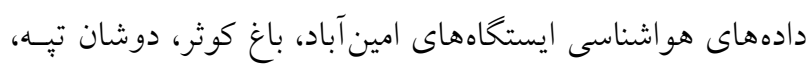

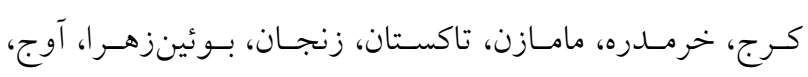

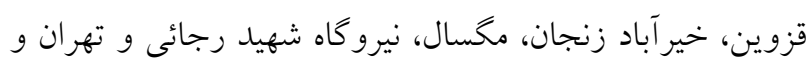

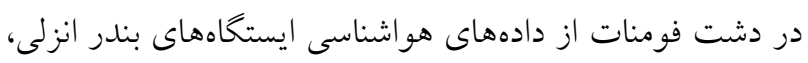

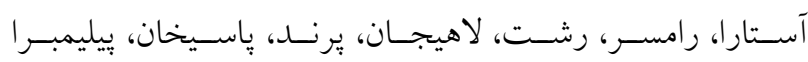
(نهالستان) و رودبار كيلان استفاده شده است. رئان.

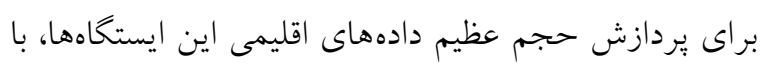

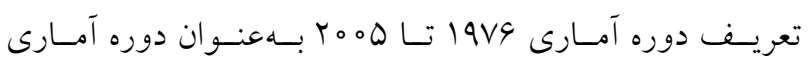
شاخص از دستور العملهاى فنس و تخصصى FAO و و سـازمان 
مناطق اطراف است بـا حـرف H نشـان داده شــــانــــ فواصـل

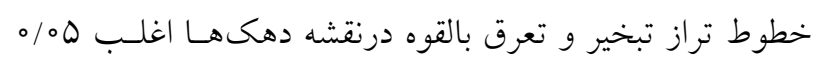

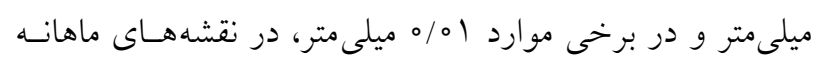

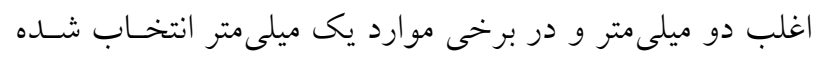

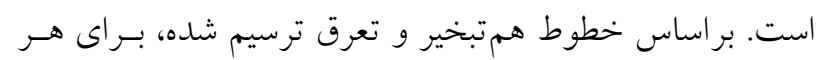

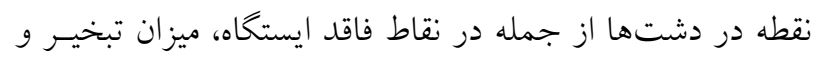

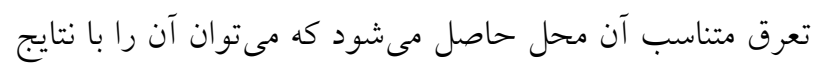

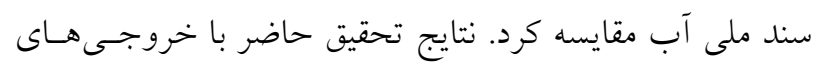
نرم|فزار OPTIWAT مقايسه مى شود. براى بررسى بهتر موضوع و درى صحيح آن، جهار ايستشاه فئاه

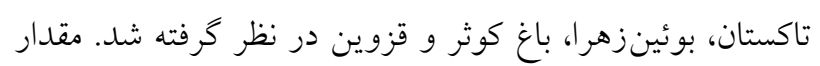

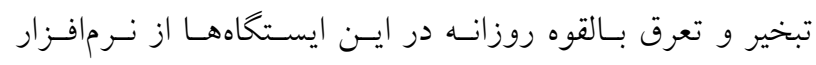

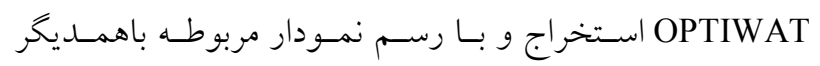

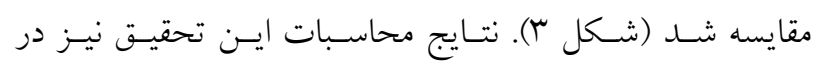
شكل (广) ارائه شده است.

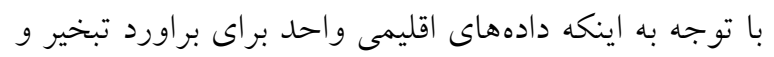

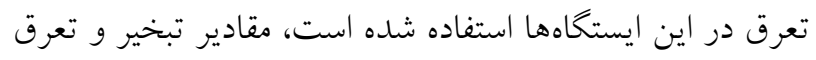

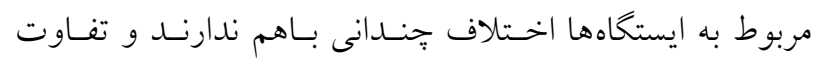

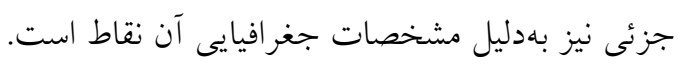

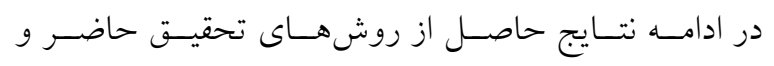

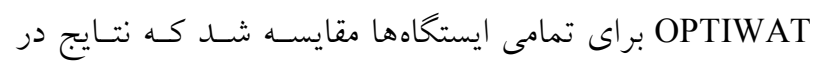

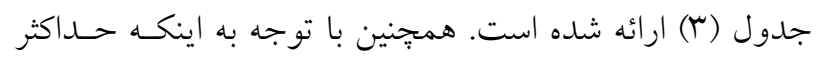

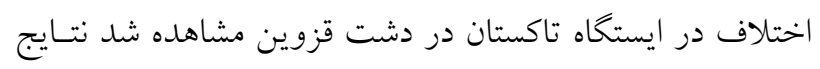
ايستخاه تاكستان بهعنوان نمونه در شكل (ه) ارائه شده است.

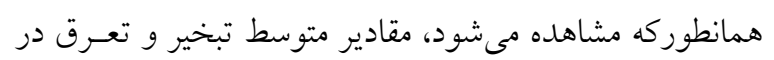

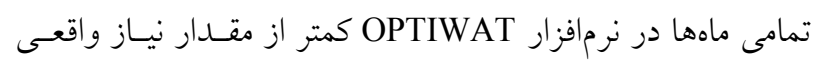

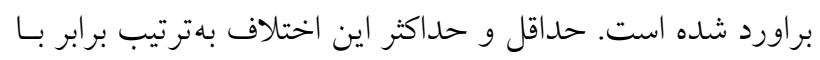

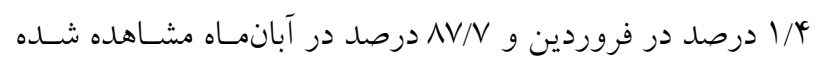

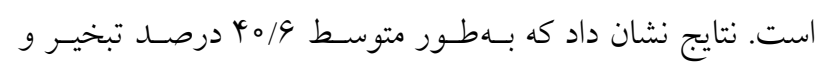

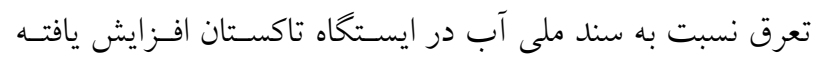

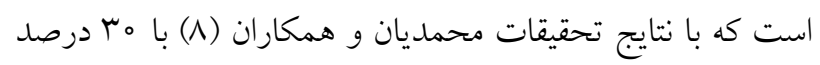

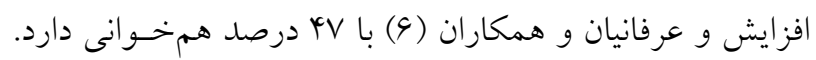

اين بارامتر، نياز به داشتن آمار دقيق هواشناسى است كه در بنـــ قبلى تشريح شد. براى كسب اطلاعات بيشتر، به آلن و همكاران (10) (1) مراجعه شود.

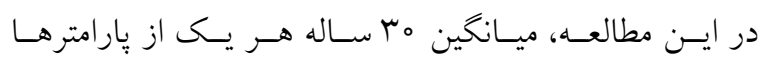

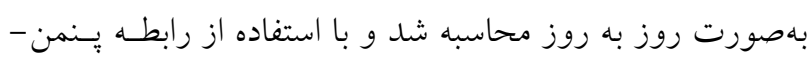

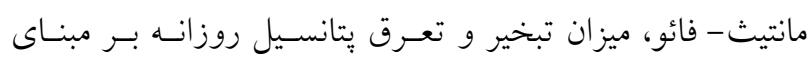

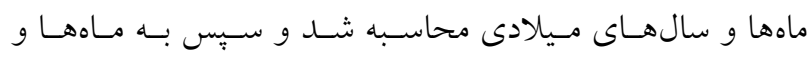

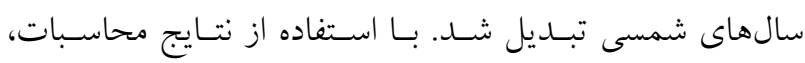
نقشههـاى دهـكهـاى اول و دوم و سـوم و ميـانخين ماهانـه و

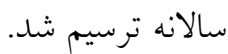

\section{نتايج و بحث}

مقدار تبخير و تعرق وِتانسيل ماهانه و سالانه محاسبه شده بـراى

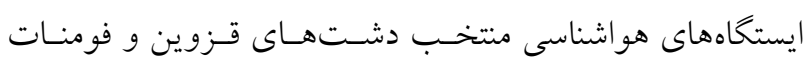

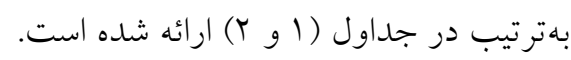

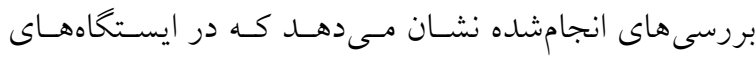

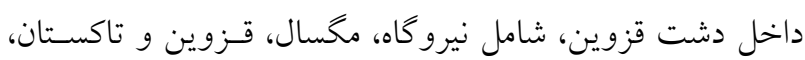

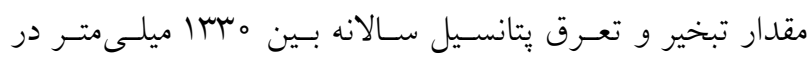

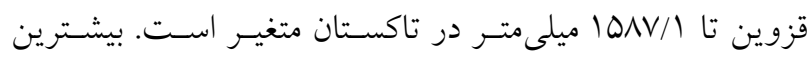

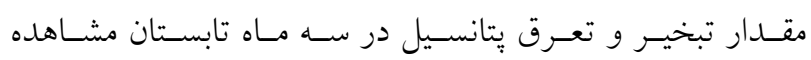

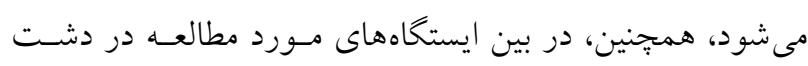

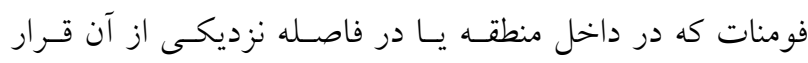

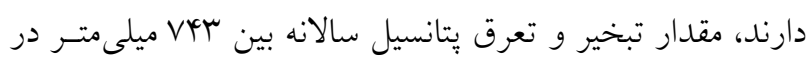

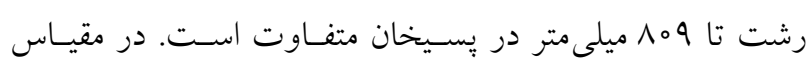

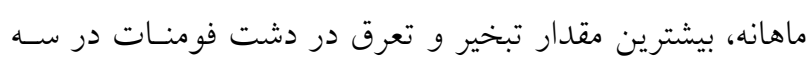
ماه خرداد، تير و مرداد مشاهده مىشود.

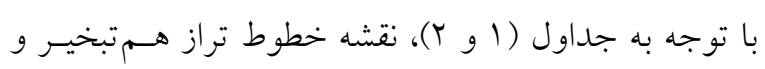

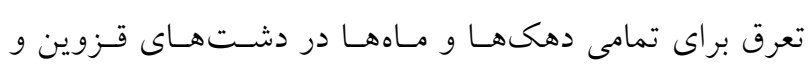

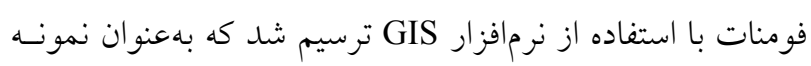

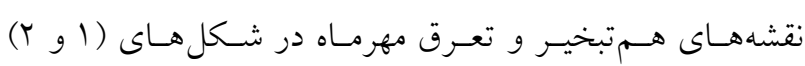
به ترتيب براى دشتهاى قزوين و فومنات ارائه شده است.

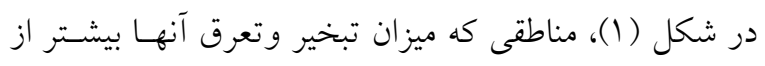




\begin{tabular}{|c|c|}
\hline$\because$ & 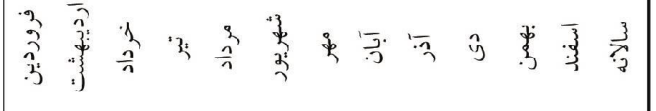 \\
\hline 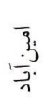 & 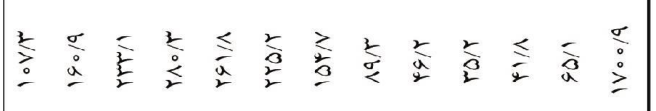 \\
\hline 至 & 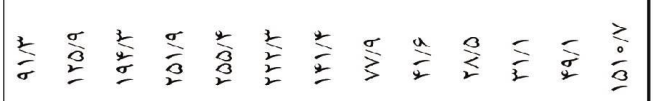 \\
\hline $\begin{array}{l}\frac{3}{3} \\
3 \\
3 .\end{array}$ & 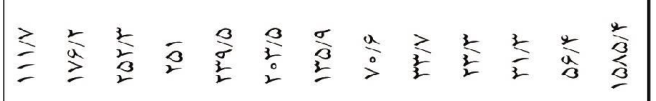 \\
\hline 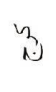 & 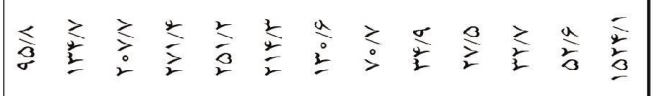 \\
\hline 3. & 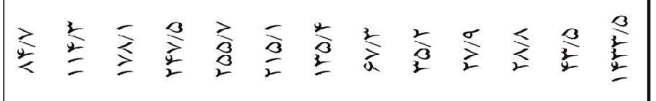 \\
\hline$\frac{3}{3}$ & 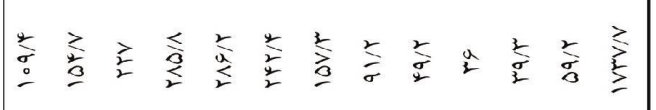 \\
\hline$\frac{3}{3}$ & 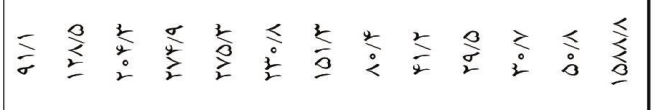 \\
\hline s & 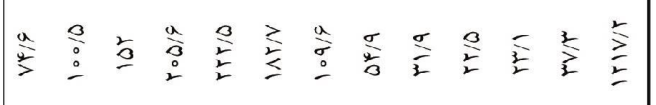 \\
\hline 'रे & 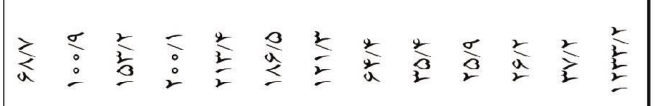 \\
\hline$\frac{3}{3}$ & 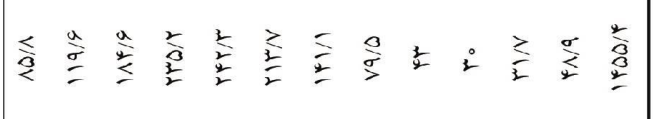 \\
\hline 3 & 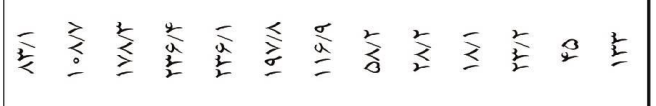 \\
\hline 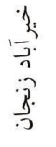 & 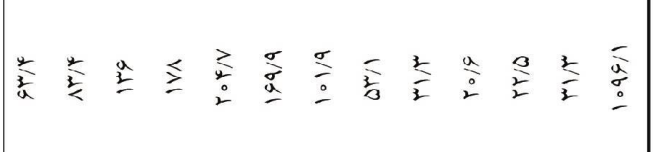 \\
\hline$y$ & 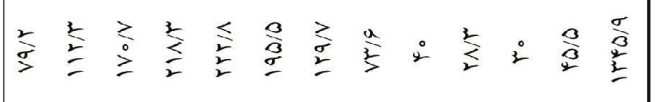 \\
\hline$\stackrel{3}{3}$ & 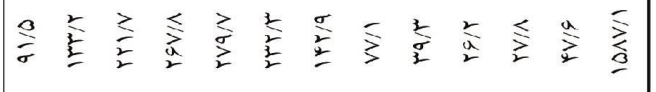 \\
\hline$\frac{7}{3}$ & 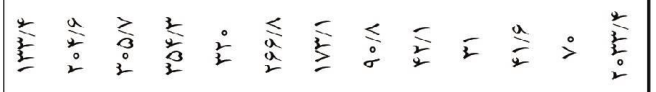 \\
\hline
\end{tabular}


جدول r. ميانخين ماهانه و جمع سالانه تبخير و تعرق (برحسب ميلىمتر) محدوده مطالعاتى دشت فومنات

\begin{tabular}{|c|c|c|c|c|c|c|c|c|c|}
\hline رودبار گيلان & ييليمبرا & ياسيخان & يرند & لاهيجان & رشت & رامسر & آستار| & بندر انزلى & ماه \\
\hline$\Lambda \mathrm{V} / \mu$ & $9 \% / 9$ & 99 & $90 / 1$ & $V Q / V$ & $\Delta \wedge / q$ & $\Delta r / r$ & $\Delta Q / \wedge$ & $\Delta Y / \Lambda$ & فروردين \\
\hline $110 / 1$ & $90 / 1$ & $9 \pi / 1$ & $19 / 9$ & $9 V / 9$ & $\Lambda Y / \varphi$ & $V G / T$ & $\Lambda \mu / \Lambda$ & $\Lambda T / l$ & ارديبهشت \\
\hline $1+9 / 0$ & $11 / 9$ & $\mid r / 1$ & $11 / 0$ & $\mid r / r$ & $11 / \mu$ & $10 / 4$ & ir & 119 & خرداد \\
\hline $100 / 9$ & r & $I T / \Lambda$ & $1 T / 9$ & $\pi / \mu$ & Ir & $11 / r$ & سזו & זسו & تير \\
\hline $14 \pi / 0$ & $1 T / \mu$ & Ir & Ir & $1 Y / 9$ & $11 / \pi$ & $10 / 9$ & IrT & س & مرداد \\
\hline $114 / 0$ & $91 / \mathrm{V}$ & $91 / \pi$ & $q \circ / r$ & $90 / 9$ & $\Lambda \circ / r$ & $\vee q / \Lambda$ & $\Lambda \varepsilon / \mu$ & $19 / r$ & شهريور \\
\hline$V \Lambda / \Delta$ & $\Delta V / \Lambda$ & $\Delta / / 1$ & $\Delta \varphi / 1$ & st & $\Delta \circ / T$ & $\Delta r / V$ & $01 / 0$ & $\Delta \omega$ & مهر \\
\hline $0 \circ / 0$ & $r y / 9$ & MI/ & $r_{0 / q}$ & $\varphi \circ / 4$ & $r N / q$ & $r \mid r$ & $r \& / q$ & $\mu_{0} / \Lambda$ & آبان \\
\hline$r q / 9$ & Tr/T & $19 / 1$ & $19 / 9$ & TN/A & $19 / \pi$ & $r \circ / 1$ & $1 V / 0$ & $r \mid / r$ & آذر \\
\hline$\mu y / l$ & TI/A & $1 N / 1$ & IV/V & $r \& / 0$ & IN/V & $1 V / 9$ & $19 / \pi$ & $1 \Lambda / \mu$ & دى \\
\hline$r \circ / r$ & $r \Lambda$ & $Y Y / Y$ & $T M / V$ & ry & TY & $Y Y / Y$ & $r \mid / \Lambda$ & $r M / l$ & بهمن \\
\hline Or & $r V / l$ & $r \Delta / \Lambda$ & T/9/9 & $x+/ q$ & TM/l & TI/s & $M I / l$ & $r \circ / 9$ & اسفند \\
\hline $10 \% \mu / 4$ & $\forall \wedge G / 1$ & KVO & $Y \Delta \Delta / V$ & $\Delta Y Q / r$ & $\mu \mu / \mu$ & $\mu r \circ / \mu$ & $90 \mathrm{~V} / \mathrm{T}$ & $V \wedge \circ / D$ & سالانه \\
\hline
\end{tabular}

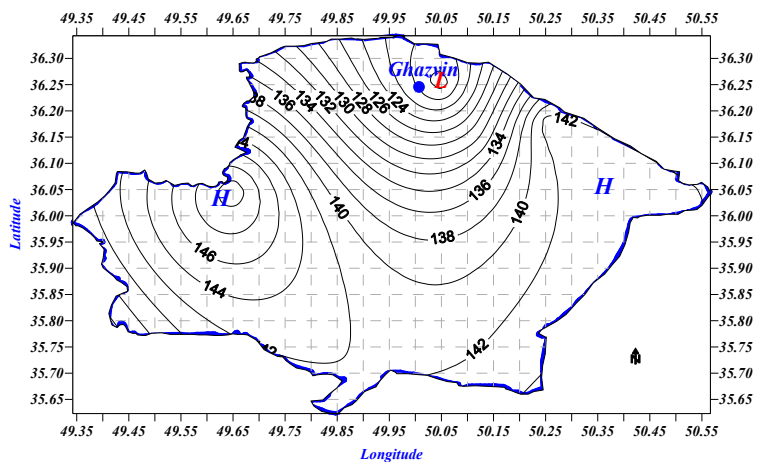

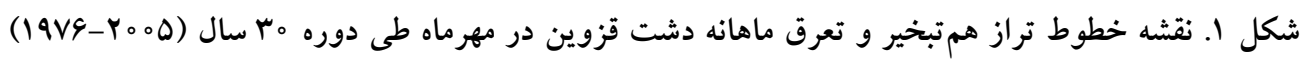

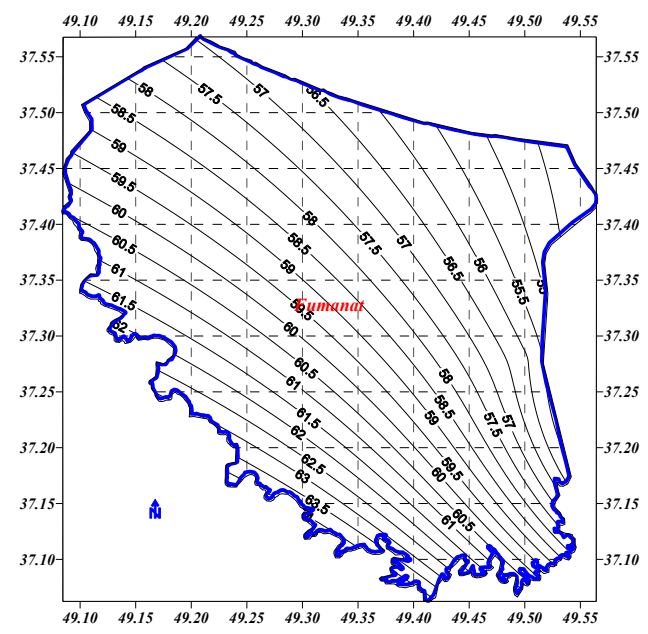

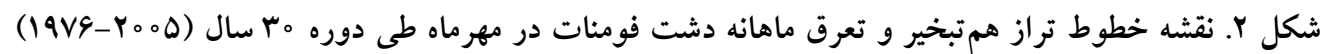




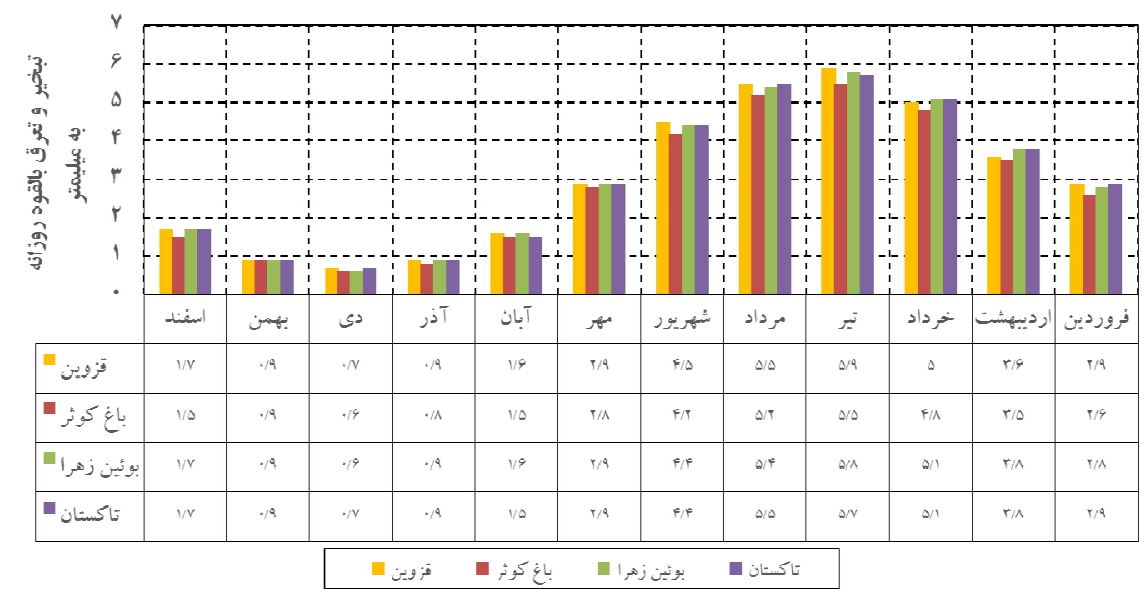

شكل r. نتايج محاسبات تبخير و تعرق بالقوه با نرمافزار OPTIWAT در ايستخاههاى منتخب. (رنخى در نسخه الكترونيكى)

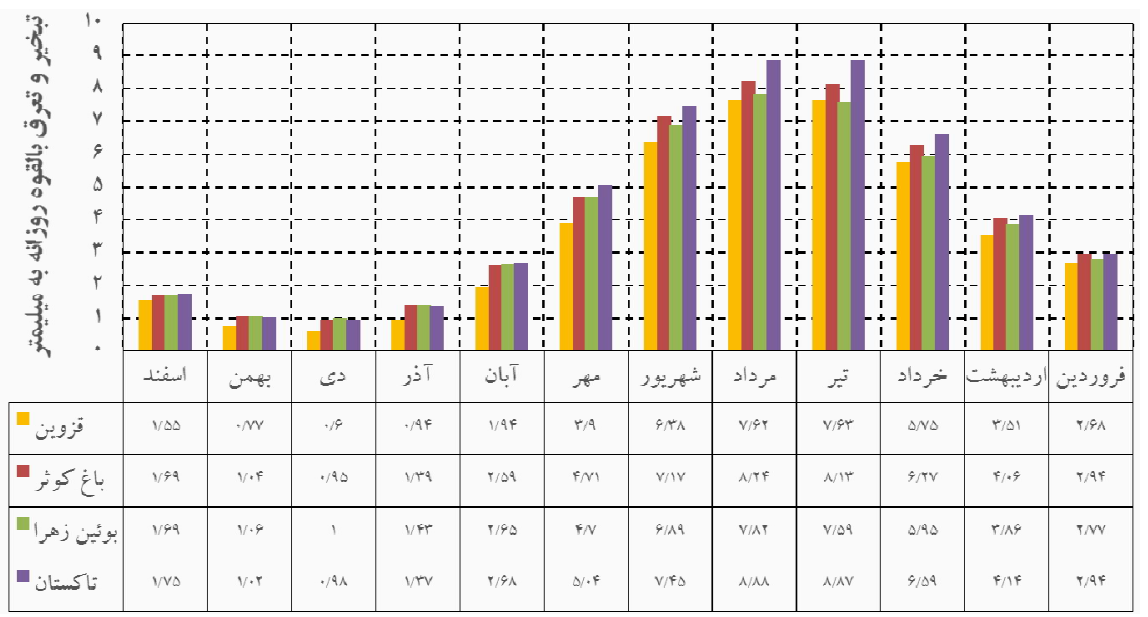

شكل ^. نتايج محاسبات تبخير و تعرق بالقوه تحقيق حاضر در ايستكاههاى منتخب

جدول r. اختلاف مشاهده شده در محاسبه نياز آبى در OPTIWAT و تحقيق حاضر (درصد)

\begin{tabular}{|c|c|c|c|c|c|c|c|c|c|c|c|c|}
\hline |سفند & بهمن & دى & آذر & آبان & مهر & شهريور & مرداد & تير & خرداد & ارديبهشت & فروردين & \\
\hline 10 & IV & IV & $r$ & 11 & rq & rq & ru & $r r$ & ir & $r$ & $\wedge$ & قزوين \\
\hline 11 & $1 r$ & $r v$ & Mr & Fr & 4 & 41 & $r V$ & rr & $\pi$ & 14 & Ir & باغ كوثر \\
\hline 1 & 10 & $y_{0}$ & rV & $y_{0}$ & $\mu$ & rq & rI & TY & 14 & r & 1 & بوئينزهرا \\
\hline r & Ir & rq & $\mu_{\mu}$ & $\mu^{4}$ & Kr & 41 & $\mu_{\Lambda}$ & ry & $r$ & $\wedge$ & 1 & تاكستان \\
\hline
\end{tabular}

نتايج نشانگر آن است كه در برخى موارد، سند ملى، ميزان نيساز اختلافها در جدول (†) ارائه شده است.

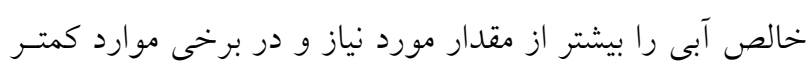

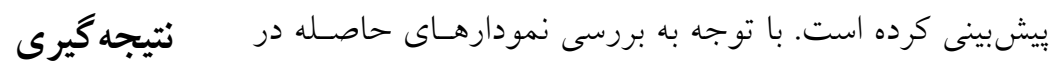

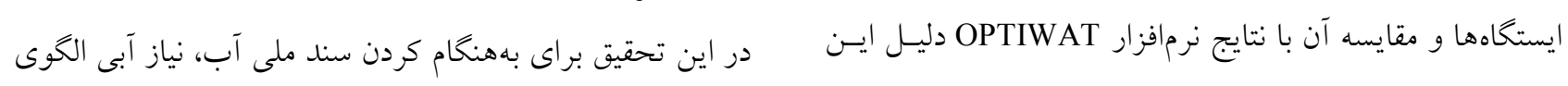




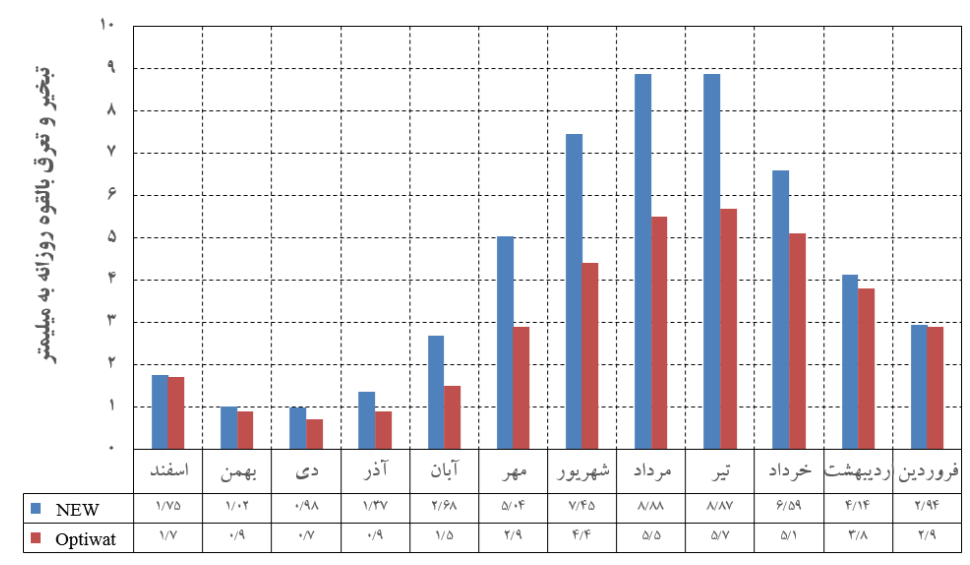

شكل ه. مقايسه نتايج محاسبه تبخير و تعرق بالقوه به روش جديد و دادهاى بِالايش شده با روش محاسبه OPTIWAT در ايستخاه تاكستان

جدTIWAT جدأ. دلايل اختلاف بين مقادير تبخير و تعرق تحقيق حاضر با نتايج نرمافزار

\begin{tabular}{|c|c|}
\hline OPTIWAT & تحقيق حاضر \\
\hline 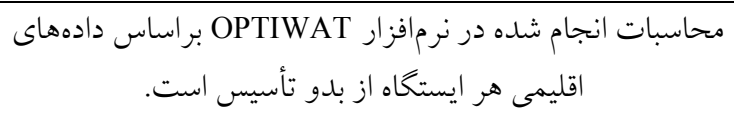 & دوره آمارى هoم ه 19V9-Y بهعنوان دوره شاخص تعريف شده است. \\
\hline 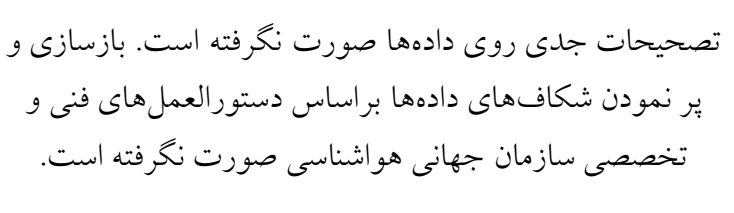 & 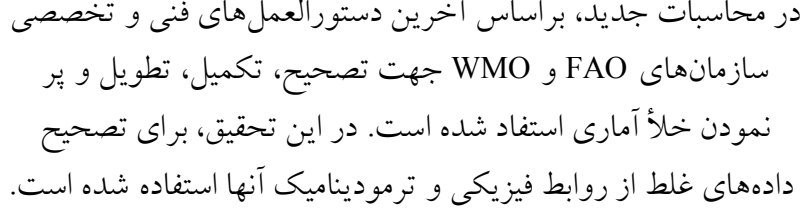 \\
\hline 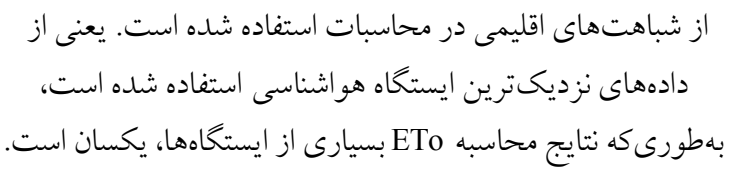 & با توجه به تعريف دوره شاخص و تنوع زياد ايستخاهها، نتايج مربوط \\
\hline
\end{tabular}

آب و OPTIWAT مشاهده شد كه بهطور متوسط

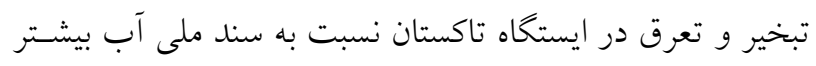

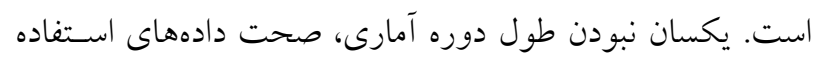

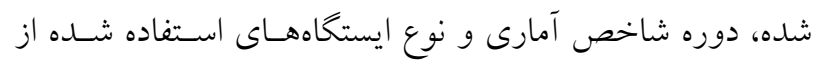

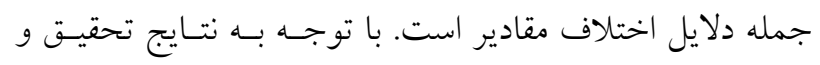

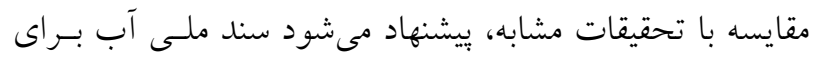
همه دشتها بازنخرى شود.
كشت كياهان بلصورت پيايلوت براى دو دشت قزوين در اسـتان

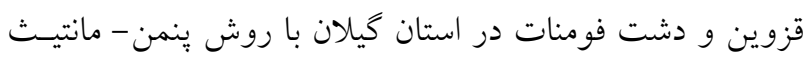

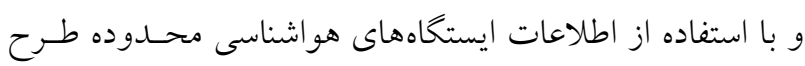

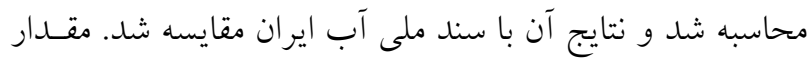

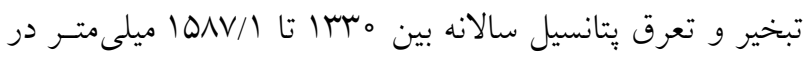

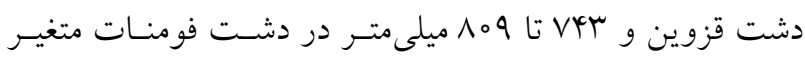

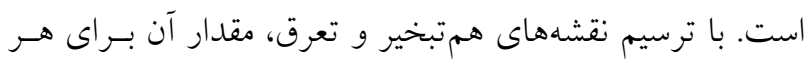

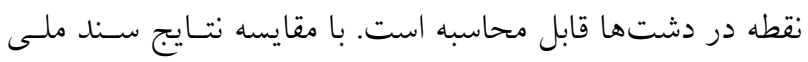

\section{منابع مورد استفاده}

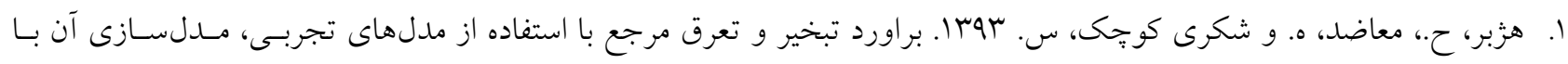


شبكه عصبى مصنوعى و مقايسه آن با دادهاى لايسيمترى در ايستخاه كهريز اروميه، فصسل نامسه مهندسسى آبيارى و آب ؟(ه ا): IT-ro

r. كريمى، س.، ج شيرى، ا. ح. ناظمى. זوبا. تخمين تبخير و تعرق روزانه گياه مرجع با اسـتفاده از سيستمهــاى هـوش مصـنوعى و و معادلههاى تجربى، نشريه دانش آب و خاك سب(YNFIS)

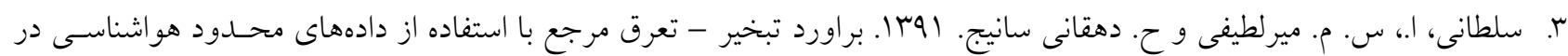

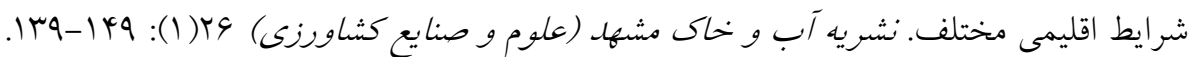

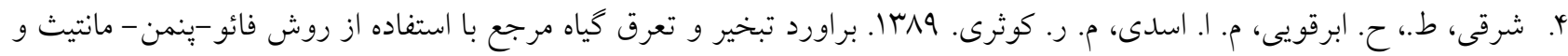

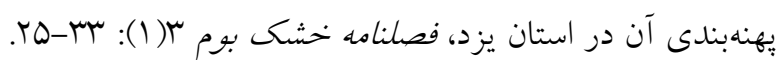

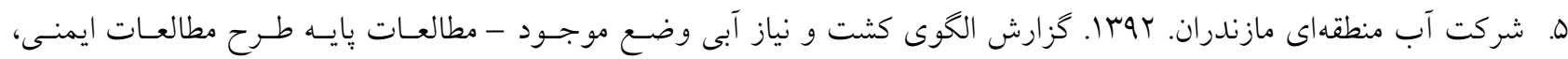
يايدارى، بهره بردارى، مرمت و بازسازى، سدهاى مخزنى و شبكه هاى آبيارى و زهكشى استان مازندران، شركت مهندسى منـابع آب وخاك. مازندارن.

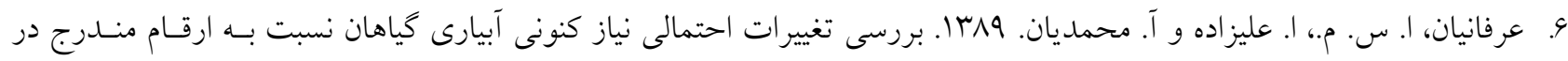

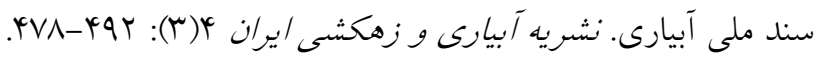

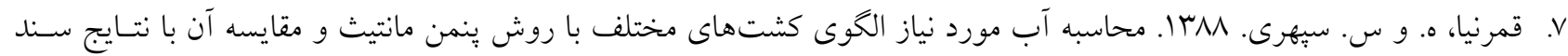
ملى آب ايران، هشتمين كنـخره بين المـللى مهنـدسى عمــران، دانشخاه شيراز.

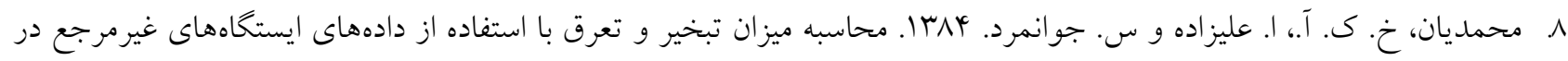

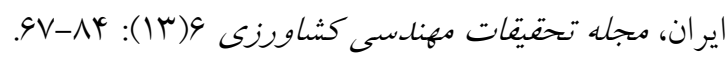

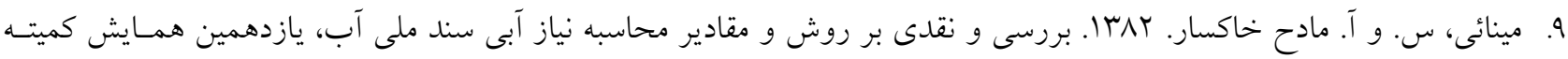
ملى آبيارى و زهكشى ايران، تهران. FA

10. Allen, R. G., L. S. Pereira, D. Reas and M. Smith. 1998. Crop Evapotranspiration. Irrigation and Drainage, FAO Rome.

11. Minaie, S. and M. A. Khaksar. 2002. Review and critique of the method of calculating the amount of water needed water Khuzestan national document. In: Proceeding of the Eleventh Congress of the Iranian National Committee on Irrigation and Drainage. 


\title{
Updating and Reviewing of the Document of National Water in Ghazvin and Fomanat Plains
}

\author{
M. Barahimi ${ }^{*}$ and I. Ghazi \\ (Received: February 8-2016 ; Accepted: September 11-2016)
}

\begin{abstract}
Determination of the required water for crop and irrigation programing is of major importance in the sustainable use of water resources. The national water document is the output of the 'net irrigation required for crops', which is presented for the optimum allocation of water resources for the demands. The Penman-Monteith-FAO method is used in the calculation. Updating the national water document is necessary to overcome its some limitations, and to provide more adaptation to the plains conditions of the country. The objective of this study was the recognition of the existing problems of the water national document and appropriate method development for implementing in the country plains. In this regard, the required water of different crop patterns was calculated using the Penman-Monteith-FAO method in the Ghazvin plain (as a dry plain), Ghazvin province, and Fomanat plain (as a wet plain), in Fomanat province, in the period of 1976-2005. The results were compared to the water national document. It was shown that annual potential evatranspiration varied between 1330 and $1587.1 \mathrm{~mm}$ in the Ghazvin plain, and between 743 and $809 \mathrm{~mm}$ in the Fomanat plain. The calculated evapotranspiration in the present study was about $40.6 \%$ more than water national document in the Takestan station, in Ghazvin plain, as a sample station.
\end{abstract}

Keywords: Dry and Wet Area, Optimum Allocation, Water Resources

1. Water Resources Department, Faculty of Civil Engineering, Shakhes Pajouh Research Institute, Isfahan, Iran.

2. Civil Engineering Department, Faculty of Civil Engineering, Shakhes Pajouh Research Institute, Isfahan, Iran.

*: Corresponding Author, Email: mbarahimi@yahoo.com 